\title{
UJI AKTIVITAS ANTIBAKTERI EKSTRAK ETANOL BUAH BELIMBING WULUH (Averrhoa bilimbi L.) ASAL KOTA WATAMPONE
}

\author{
St. Maryam, Saidah juniasti, Rachmat Kosman \\ Fakultas Farmasi Universitas Muslim Indonesia \\ Email: st.maryam_apt@yahoo.com.
}

\begin{abstract}
It has been conducted the research on Assay of Antibacterial Activity of Ethanolic Extract of Wuluh Starfruit (Averrhoa bilimbi L.) The aim of this research is to determine the antibacterial activity. The initial screening assay conducted on several bacteria including Escheria coli, Pseudomonas aeruginosa, Salmonella typhi, Bacillus subtilis, Staphylococcus aureus, Streptococcus mutans, Vibrio cholerae, Shigella dysenteriae. Then, assay on the Minimum Inhibition Concentration (MIC) was carried out with some variations of concentration: $0,05 \% ; 0,1 \% ; 0,2 \% ; 0,4 \%$; $0,8 \%$; and 1,6\%. Test result of MIC was then followed by MKC test (Minimum Kill Concentration) using NA medium. The results showed that on concentration $0,4 \%$; $0,8 \%$; and $1,6 \%$ inhibit the growth of bacteria tested. Antibacterial activity of ethanolic extract of wuluh starfruit (Averrhoa bilimbi L.) was conducted by using the diffusion agat method. The result showed that the lowest concentration 0,4\% ethanolic extract of wuluh starfruit (Averrhoa bilimbi L.) inhibit the growth of bacteria Shigella dysenteriae, Salmonella typhi, Pseudomonas aeruginosa, Vibrio cholerae, Escherichia coli and Staphylococcus aureus.
\end{abstract}

Key Words : Wuluh starfruit, Antibacteria, Diffusion Agar.

\section{PENDAHULUAN}

Belimbing wuluh (Averrhoa

bilimbi L.) merupakan salah satu jenis tanaman yang sering digunakan sebagai obat tradisional. Tanaman ini banyak di manfaatkan untuk mengatasi berbagai penyakit seperti batuk, diabetes, rematik, gondongan, sariawan, sakit gigi, gusi berdarah, jerawat, diare sampai tekanan darah tinggi (Wijayakusuma, 2006). Buah belimbing wuluh (Averrhoa bilimbi L.) adalah salah satu tanaman yang banyak tumbuh di pekarangan dan dimanfaatkan oleh masyarakat Indonesia. Tanaman ini tumbuh subur di Indonesia, Filipina, Sri Langka, Myanmar, dan Malaysia. Kelebihan tanaman ini adalah termasuk salah satu jenis tanaman tropis yang dapat berbuah sepanjang tahun (Parikesit, 2011).

Salah satu tanaman obat di Indonesia yang telah populer karena 
Uji Aktivitas Antibakteri Ekstrak Etanol Buah Belimbing Wuluh (verrhoa bilimbi L.) Asal kota watampone

mudah diperoleh adalah belimbing wuluh (Averrhoa bilimbi L.) (Hembing, 2008). Bagian dari tanaman ini yang dapat dimanfaatkan adalah batang, daun, bunga serta buahnya (Muhlisah, 2007). Menurut (Herlih,1993) dari hasil pemeriksaan kandungan kimia buah belimbing wuluh (Averrhoa bilimbi L.) mengandung golongan senyawa oksalat, minyak menguap, fenol, flavonoid, dan pectin.

Buah belimbing wuluh mengandung zat flavonoid, tanin, dan saponin yang telah teruji klinis memiliki efek antibakteri terhadap beberapa jenis bakteri salah satunya pada bakteri Shigella dysenteriae (Chusnie, 2005). Menurut penelitian yang dilakukannya oleh Prayogo (2011), membuktikan bahwa sari buah belimbing wuluh (Averrhoa bilimbi L.) dapat menghambat pertumbuhan bakteri Aeromonas Salmonicida smithia. Penelitian ini akan dilakukan pengujian aktivitas antibakteri menggunakan ekstrak etanol buah belimbing wuluh (Averrhoa bilimbi L.) yang diperoleh dari kota watampone, terhadap beberapa bakteri patogen diantaranya Escherichia coli, Staphylococcus aureus, Pseudomonas aeruginosa, Vibrio cholerae, Bacillus subtilis, Streptococcus mutans, Salmonella typhi, dan Shigella dysenteriae. Dengan mengetahui adanya aktivitas antibakteri buah belimbing wuluh (Averrhoa bilimbi L.) diharapkan dapat mengembangkan potensi pendayagunaan tanaman obat berkhasiat yang ada di Indonesia.

\section{METODE PENELITIAN}

\section{Alat dan Bahan}

Adapun alat yang digunakan adalah Erlenmeyer (Iwaki Pyrex), gelas kimia (Iwaki Pyrex), inkubator (Memert), autoklaf, batang pengaduk, bejana maserasi, cawan petri, oven, lampu spiritus, botol vial, tabung reaksi, pinset, ose bulat, penangas air, penggaris, timbangan analitik.

Bahan yang dipakai adalah air suling steril, alkohol $70 \%$, alkohol $96 \%$, biakan mikroba uji, DMSO, disk blank, larutan $\mathrm{NaCl}$ 0,9 \%, medium Nutrien Agar (NA), medium Nutrien Broth (NB), dan sampel buah belimbing wuluh (Averrhoa bilimbi L.)

\section{Prosedur Penelitian}

\section{Pengambilan sampel}

Sampel buah belimbing wuluh (Averrhoa bilimbi L.) diperoleh dari kota Watampone

\section{Pengolahan sampel}

Buah belimbing wuluh (Averrhoa bilimbi L.) dibersihkan dari kotoran-kotoran yang melekat dengan menggunakan air yang mengalir, kemudian dikeringkan dengan cara 
Uji Aktivitas Antibakteri Ekstrak Etanol Buah Belimbing Wuluh (verrhoa bilimbi L.) Asal kota watampone

diangin-anginkan atau terkena sinar matahari langsung.

\section{Pembuatan ekstrak buah belimbing wuluh (Averrhoa bilimbi L.)}

Buah belimbing wuluh (Averrhoa bilimbi L.) segar yang telah dipetik dibersihkan dari kotoran, dicuci dengan air sampai bersih dan ditiriskan, kemudian dipotong-potong tipis. Selanjutnya, buah belimbing wuluh (Averrhoa bilimbi L.) tersebut dikeringkan dengan menggunakan oven pada suhu 40-50oC sampai kadar air buah belimbing wuluh (Averrhoa bilimbi L.) tersebut menjadi $\pm 10 \%$. Selanjutnya, pembuatan ekstrak ini menggunakan cara maserasi, yaitu dengan merendam buah belimbing wuluh (Averrhoa bilimbi L.) kedalam bejana maserasi yang terbuat dari toples kaca kemudian diberi larutan etanol 96\% sampai buah terendam sempurna. Bejana maserasi tersebut ditutup rapat dan didiamkan selama \pm 3 hari sambil diaduk satu kali setiap hari. Setelah itu disaring dan ampasnya direndam lagi dengan cairan penyari yang baru, hal ini dilakukan hingga proses ekstraksi sempurna, hasil penyarian yang didapat kemudian diuapkan dengan cara diangin-anginkan hingga diperoleh ekstrak etanol kental.

\section{Penyiapan bakteri uji}

\section{Peremajaan bakteri uji}

Peremajaan kultur murni mikroba uji. Bakteri diambil dari biakan masing-masing satu ose kemudian diinokulasi pada medium NA miring. Masing-masing bakteri diinkubasi selama 24 jam pada suhu $37^{\circ} \mathrm{C}$. Setelah itu dapat digunakan sebagai bakteri uji.

\section{Pembuatan suspensi bakteri uji}

Bakteri uji hasil peremajaan, masing-masing disuspensikan dengan larutan $\mathrm{NaCl}$ fisiologi 0,9\% dan dimasukkan kedalam kuvet, kemudian diukur transmitanya menggunakan spektrofometer dengan panjang gelombang $580 \mathrm{nM}$ pada $25 \% \mathrm{~T}$ untuk bakteri. Sebagai blanko digunakan $\mathrm{NaCl}$ fisiologi $0,9 \%$.

\section{Pengujian skrining antibakteri}

Ekstrak buah belimbing wuluh (Averrhoa bilimbi L.) ditimbang sebanyak $10 \mathrm{mg}$ lalu dilarutkan dengan DMSO sebanyak 0,2 mL. Setelah larut ditambahkan medium NA 9,8 $\mathrm{mL}$ sehingga diperoleh konsentrasi $1 \mathrm{mg} / \mathrm{mL}$. Campuran tersebut dituang kedalam cawan petri lalu dihomogenkan dan dibiarkan memadat. Mikroba yang telah disuspensikan, masing-masing diambil dengan menggunakan ose bulat lalu 
Uji Aktivitas Antibakteri Ekstrak Etanol Buah Belimbing Wuluh (verrhoa bilimbi L.) Asal kota watampone

digoreskan diatas medium. Kemudian di inkubasi pada suhu $370 \mathrm{C}$ selama 1 x 24 jam. Setelah itu diamati aktivitas antimikrobanya yang ditandai dengan ada atau tidaknya pertumbuhan bakteri.

\section{Uji aktivitas antibakteri}

\section{Uji konsentrasi Hambat Minimum}

Pengujian KHM dilakukan terhadap bakteri yang memberikan hasil positif $(+)$ pada uji skrining aktifitas antibakteri dari ekstrak buah belimbing wuluh (Averrhoa bilimbi L.) Pengujian ini dilakukan dengan konsentrasi $0,05 \%, 0,1 \%$, $0,2 \%, \quad 0,4 \%, \quad 0,8 \%$ dan $1,6 \%$. Sampel ditimbang sesuai dengan konsentrasi yang akan dibuat terhadap $5 \mathrm{~mL}$ medium NB dalam vial, dilarutkan dengan DMSO, ditambah $5 \mathrm{~mL} \mathrm{NB}$, dihomogenkan dan dimasukkan kedalam tabung reaksi steril, selanjutnya dimasukkan mikroba uji yang positif pada uji skrining aktivitas antibakteri kedalam tiap tabung. Konsentrasi terendah dari sampel ekstrak buah belimbing wuluh (Averrhoa bilimbi L.) dengan parameter dimana larutan tampak jernih setelah inkubasi dinyatakan sebagai harga KHM.

\section{Uji konsentrasi Bunuh Minimum}

Hasil inkubasi pada uji KHM kemudian digoreskan pada medium NA pada cawam petri, lalu dinkubasi pada suhu $370 \mathrm{C}$ selama $1 \times 24$ jam. Pada Konsentrasi terendah buah belimbing wuluh (Averrhoa bilimbi L.) yang bersifat antibakteri dimana apabila hasilnya berupa daerah tanpa pertumbuhan setelah inkubasi, menunjukkan harga KBM.

\section{Pengujian aktivitas antibakteri secara difusi agar}

Medium NA steril yang telah dipanaskan dan disterilkan kemudian didinginkan hingga suhu 40-50oC. Dimasukkan secara aseptis ke dalam cawan petri sebanyak $10 \mathrm{~mL}$ dan 0,2 $\mathrm{mL}$ suspensi mikroba uji, lalu dihomogenkan dengan memutar cawan petri, didiamkan hingga memadat, kemudian disk blank yang telah ditetesi dengan ekstrak buah belimbing wuluh (Averrhoa bilimbi L.) dengan beberapa variasi konsentrasi sebanyak $0,2 \mathrm{~mL}$ diletakkan secara aseptis selanjutnya diinkubasi bakteri pada suhu $370 \mathrm{C}$ selama $1 \times 24$ jam dalam inkubator, kemudian dilakukan pengamatan dan pengukuran zona hambatan yang terbentuk. 
Uji Aktivitas Antibakteri Ekstrak Etanol Buah Belimbing Wuluh (vverrhoa bilimbi L.) Asal kota watampone

\section{HASIL PENELITIAN}

Tabel 1. Hasil uji skrining aktivitas antibakteri ekstrak etanol buah belimbing wuluh (Averrhoa bilimbi L.)

\begin{tabular}{ccccccccc}
\hline \multirow{2}{*}{ Konsentrasi } & \multicolumn{8}{c}{ Bakteri Uji } \\
\cline { 2 - 9 } & BS & EC & SA & SD & SM & ST & PA & VC \\
\hline $0,5 \%$ & + & + & + & + & + & + & + & + \\
$0,1 \%$ & + & + & + & + & + & + & + & + \\
\hline Keterangan : & & & & & & & \\
BS :Bacillus subtilis & & & & ST & :Salmonella typhi \\
EC :Escherichia coli & & & PA & $:$ Pseudomonas aeruginosa \\
SA :Staphylococcus aureus & & & VC & :Vibrio cholerae \\
SD :Shigella dysenteriae & & & & + & $:$ :menghambat pertumbuhan bakteri \\
SM :Streptococcus mutans & & & - & : tidak menghambatpertumbuhan bakteri
\end{tabular}

Tabel 2. Hasil uji Konsentrasi Hambat Minimum (KHM) ekstrak etanol buah belimbing wuluh (Averrhoa bilimbi L.) terhadap beberapa bakteri uji

\begin{tabular}{ccccccc}
\hline \multirow{2}{*}{ Bakteri } & \multicolumn{7}{c}{ Konsentrasi ekstrak etanol buah belimbing wuluh } \\
& \multicolumn{7}{c}{ (Averrhoa bilimbi L.) } \\
\cline { 2 - 7 } & $\mathbf{0 , 0 5 \%}$ & $\mathbf{0 , 1 \%}$ & $\mathbf{0 , 2} \%$ & $\mathbf{0 , 4 \%}$ & $\mathbf{0 , 8 \%}$ & $\mathbf{1 , 6 \%}$ \\
\hline Bacillus subtilis & + & + & + & + & + & + \\
Escherichia coli & + & + & + & + & + & + \\
Staphylococcus aureus & + & + & + & + & + & + \\
Shigella dysenteriae & + & + & + & + & + & + \\
Streptococcus mutans & + & + & + & + & + & + \\
Salmonella typhi & + & + & + & + & + & + \\
Pseudomonas aeruginosa & + & + & + & + & + & + \\
Vibrio cholerae & + & + & + & + & + & + \\
\hline
\end{tabular}

\section{Keterangan :}

+ : menghambat pertumbuhan bakteri

- : tidak menghambat pertumbuhan bakteri

Tabel 3. Hasil uji Konsentrasi Bunuh Minimum (KBM) ekstrak etanol buah belimbing wuluh (Averrhoa bilimbi L.) terhadap beberapa bakteri uji

\begin{tabular}{ccccccc}
\hline \multirow{2}{*}{ Bakteri } & \multicolumn{7}{c}{ Konsentrasi ekstrak etanol buah belimbing wuluh } \\
& \multicolumn{5}{c}{ (Averrhoa bilimbi L.) } \\
\cline { 2 - 7 } & $\mathbf{0 , 0 5 \%}$ & $\mathbf{0 , 1 \%}$ & $\mathbf{0 , 2} \%$ & $\mathbf{0 , 4 \%}$ & $\mathbf{0 , 8 \%}$ & $\mathbf{1 , 6 \%}$ \\
\hline Bacillus subtilis & - & - & - & + & + & + \\
Escherichia coli & - & - & - & + & + & + \\
Staphylococcus aureus & - & - & - & + & + & + \\
Shigella dysenteriae & - & - & - & + & + & + \\
Streptococcus mutans & - & - & - & + & + & + \\
Salmonella typhi & - & - & - & + & + & + \\
Pseudomonas aeruginosa & - & - & - & + & + & + \\
Vibrio cholerae & - & - & - & + & + & + \\
\hline
\end{tabular}

\section{Keterangan :}

+ : menghambat pertumbuhan bakteri

- : tidak menghambat pertumbuhan bakteri 
Uji Aktivitas Antibakteri Ekstrak Etanol Buah Belimbing Wuluh (verrhoa bilimbi L.) Asal kota watampone

Tabel 4. Hasil pengujian aktivitas ekstrak etanol buah belimbing wuluh (Averrhoa bilimbi L.) terhadap beberapa bakteri uji dengan metode difusi agar

\begin{tabular}{|c|c|c|c|}
\hline \multirow{2}{*}{ Bakteri } & \multicolumn{3}{|c|}{$\begin{array}{c}\text { Diameter zona hambat ekstrak etanol buah belimbing } \\
\text { wuluh (Averrhoa bilimbi L.) }\end{array}$} \\
\hline & $0,4 \%$ & $0,8 \%$ & $1,6 \%$ \\
\hline \multirow{3}{*}{ Bacillus subtilis } & 0 & 8 & 10 \\
\hline & 0 & 8 & 11 \\
\hline & 0 & 9 & 11 \\
\hline \multirow[t]{2}{*}{ Rata-rata } & 0 & 8,33 & 10,67 \\
\hline & 7 & 9 & 11 \\
\hline \multirow[t]{2}{*}{ Escherichia coli } & 7 & 8 & 10 \\
\hline & 7 & 7 & 10 \\
\hline \multirow[t]{2}{*}{ Rata-rata } & 7 & 8 & 10,33 \\
\hline & 7 & 9 & 13 \\
\hline \multirow[t]{2}{*}{ Staphylococcus aureus } & 7 & 9 & 13 \\
\hline & 7 & 9 & 13 \\
\hline \multirow[t]{2}{*}{ Rata-rata } & 7 & 9 & 13 \\
\hline & 7 & 8 & 13 \\
\hline \multirow[t]{2}{*}{ Shigella dysenteriae } & 7 & 8 & 12 \\
\hline & 7 & 8 & 12 \\
\hline \multirow[t]{2}{*}{ Rata-rata } & 7 & 8 & 12,33 \\
\hline & 0 & 9 & 13 \\
\hline \multirow[t]{2}{*}{ Streptococcus mutans } & 0 & 9 & 13 \\
\hline & 0 & 9 & 13 \\
\hline \multirow[t]{2}{*}{ Rata-rata } & 0 & 9 & 13 \\
\hline & 8 & 8 & 12 \\
\hline \multirow[t]{2}{*}{ Salmonella typhi } & 8 & 8 & 12 \\
\hline & 8 & 9 & 12 \\
\hline \multirow[t]{2}{*}{ Rata-rata } & 8 & 8,33 & 12 \\
\hline & 9 & 9 & 12 \\
\hline \multirow[t]{2}{*}{ Pseudomonas aeruginosa } & 8 & 9 & 12 \\
\hline & 8 & 9 & 12 \\
\hline \multirow[t]{2}{*}{ Rata-rata } & 8,33 & 9 & 12 \\
\hline & 9 & 10 & 12 \\
\hline \multirow[t]{2}{*}{ Vibrio cholera } & 9 & 10 & 12 \\
\hline & 9 & 10 & 12 \\
\hline Rata-rata & 9 & 10 & 12 \\
\hline
\end{tabular}

\section{PEMBAHASAN}

Belimbing wuluh (Averrhoa bilimbi L.) merupakan salah satu tanaman yang berkhasiat sebagai obat. Belimbing wuluh (Averrhoa bilimbi L.) tidak terlalu membutuhkan banyak air untuk merawatnya dan dapat berkembang ditempat yang lembab. Tanaman belimbing wuluh telah dimanfaatkan sebagai obat tradisional. Adapun kandungan bahan kimia alami dari buah belimbing wuluh yang diketahui mempunyai efek antibakteri yaitu, flavonoid dan fenol (Hembing, 2008). Karena berdasarkan literatur bagian buah belimbing wuluh 
Uji Aktivitas Antibakteri Ekstrak Etanol Buah Belimbing Wuluh (verrhoa bilimbi L.) Asal kota watampone

(Averrhoa bilimbi L.) digunakan sebagai obat batuk, diabetes, rematik, gondongan, sariawan, sakit gigi, gusi berdarah, jerawat, diare sampai tekanan darah tinggi.

Proses ekstraksi komponen kimia pada simplisia dengan menggunakan metode maserasi karena alatnya yang sederhana dan mudah dilakukan. Cairan penyari yang digunakan adalah etanol karena tidak bersifat toksik.

Ekstrak etanol kental yang telah diperoleh, dilanjutkan dengan pengujian skrining (Tabel 1) dimana dalam penelitian ini menggunakan 8 bakteri uji yaitu Escherichia coli, Pseudomonas aeruginosa, Salmonella typhi, Bacillus subtilis, Staphylococcus aureus, Streptococcus mutans, Vibrio cholerae, Shigella dysenteria.

Ekstrak uji dilarutkan dengan Dimetil Sulfoksida (DMSO) karena merupakan pelarut yang bersifat semi polar yang dapat melarutkan komponen kimia polar dan non polar tanpa memberikan penghambatan terhadap mikroba uji. Medium Nutrien Agar (NA) merupakan medium agar yang digunakan pada metode dilusi padat dan untuk menumbuhkan biakan bakteri uji. Sedangkan medium Nutrien Broth (NB) merupakan medium cair yang digunakan pada pengujian
Konsentrasi Hambat Minimum (KHM). Bakteri uji yang digunakan dalam penelitian ini terlebih dahulu dibuat dalam bentuk suspensi bakteri, dengan cara diukur transmitannya dengan menggunakan spektrofotometer pada panjang gelombang maksimum $580 \mathrm{nM}$. Transmitan untuk bakteri adalah 25\% $\mathrm{T}$ karena ukuran bakteri yang kecil sehingga lebih banyak yang terserap.

Berdasarkan pengujian skrining terhadap beberapa bakteri diperoleh hasil bahwa ekstrak etanol buah belimbing wuluh (Averrhoa bilimbi L.) pada konsentrasi $0,5 \%$ dan $0,1 \%$ dapat menghambat pertumbuhan bakteri Escherichia coli, Pseudomonas aeruginosa, Salmonella typhi, Bacillus subtilis, Staphylococcus aureus, Streptococcus mutans, Vibrio cholerae, Shigella dysenteriae.

Dari hasil pengujian skrining kemudian dilanjutkan dengan pengujian KHM. Tujuan pengujian KHM yaitu untuk menentukan nilai konsentrasi minimum dari suatu sampel dalam menghambat pertumbuhan bakteri uji. Konsentrasi terendah yang terlihat jernih tanpa adanya pertumbuhan bakteri dan ditetapkan sebagai nilai KHM-nya. Berdasarkan pengujian tersebut diperoleh hasil KHM (Tabel 2) yang 
Uji Aktivitas Antibakteri Ekstrak Etanol Buah Belimbing Wuluh (verrhoa bilimbi L.) Asal kota watampone

menunjukkan kejernihan pada

metode ini, kita dapat mengukur keseluruhan konsentrasi terhadap semua bakteri yang diujikan.

Penentuan KBM dilakukan dengan menggoreskan sampel hasil KHM pada medium NA di cawan petri. Tujuan pengujian KBM dimaksdukan untuk melihat kadar bunuh minimum dari suatu sampel uji. Konsentrasi terendah dari sampel yang masih dapat membunuh bakteri merupakan nilai KBM yang ditunjukkan dengan ada tidanya pertumbuhan bakteri pada medium yang telah diinkubasi.

Setelah diperoleh nilai KBM (Tabel 3), maka dilanjutkan dengan pengujian aktivitas antibakteri dengan metode difusi agar (Tabel 4). Bakteri yang digunakan yaitu Escherichia coli, Pseudomonas aeruginosa, Salmonella typhi, Bacillus subtilis, Staphylococcus aureus, Streptococcus mutans, Vibrio cholerae, Shigella dysenteriae.

Berdasarkan KBM maka dapat ditentukan variasi konsentrasi ekstrak yang dapat memberikan aktivitas sebagai antibakteri. Konsentrasi yang digunakan yaitu 0,4\%, 0,8\% dan 1,6\%. Pada pengujian ini digunakan disk blank untuk melihat zona hambatan yang terbentuk.

Metode difusi adalah proses perpindahan molekul secara acak dari satu posisi ke posisi lain. Keuntungan seberapa besar zona hambatan yang terbentuk. Uji ini dilakukan dengan menggunakan disk blank. Zona hambatan merupakan zona bening yang terbentuk disekitar disk blank karena tidak adanya pertumbuhan bakteri uji yang disebabkan adanya zat yang menghambat pertumbuhan bakteri uji yang terdapat pada sampel uji yang dikeluarkan melalui disk blank yang berdifusi ke medium. Penggunaan disk blank mempunyai keuntungannya itu proses difusinya cepat, mudah dalam pengerjaan. Jadi zona hambat terbentuk karena sampel uji yang digunakan terserap masuk ke disk blank lalu disk blank berdifusi ke medium sehingga menghasilkan zona hambat.

Pada uji aktivitas buah belimbing wuluh (Averrhoa bilimbi L.) digunakan tiga konsentrasi yaitu $0,4 \%$, 0,8\%, dan 1,6\%, diperoleh hasil dengan terbentuknya zona bening disekitar disk blank dengan diameter rata-rata tiap bakteri adalah untuk bakteri Bacillus subtilis pada konsentrasi $0,4 \%$ tidak menghambat, konsentrasi $0,8 \%$ yaitu $8,33 \mathrm{~mm}$ dan konsentrasi $1,6 \%$ yaitu $10,67 \mathrm{~mm}$. Bakteri Escherichia coli pada konsentrasi $0,4 \%$ yaitu $7 \mathrm{~mm}$, konsentrasi $0,8 \%$ yaitu $8 \mathrm{~mm}$, 
Uji Aktivitas Antibakteri Ekstrak Etanol Buah Belimbing Wuluh (verrhoa bilimbi L.) Asal kota watampone

konsentrasi $1,6 \%$ yaitu $10,33 \mathrm{~mm}$.

Bakteri Staphylococcus aureus pada konsentrasi $0,4 \%$ yaitu $7 \mathrm{~mm}$, konsentrasi $0,8 \%$ yaitu $9 \mathrm{~mm}$, konsentrasi $1,6 \%$ yaitu $13 \mathrm{~mm}$. Bakteri Shigella dysenteriae pada konsentrasi $0,4 \%$ yaitu $7 \mathrm{~mm}$, konsentrasi $0,8 \%$ yaitu $8 \mathrm{~mm}$, konsentrasi 1,6\% yaitu 12,33. Bakteri Streptococcus mutans pada konsentrasi $0,4 \%$ tidak menghambat, konsentrasi $0,8 \%$ yaitu 9 $\mathrm{mm}$, konsentrasi $1,6 \%$ yaitu $13 \mathrm{~mm}$. Bakteri Salmonella typhi pada konsentrasi $0,4 \%$ yaitu $8 \mathrm{~mm}$, konsentrasi $0,8 \%$ yaitu $8,33 \mathrm{~mm}$, konsentrasi $1,6 \%$ yaitu $12 \mathrm{~mm}$. Bakteri Pseudomonas aeruginosa pada konsentrasi $0,4 \%$ yaitu $8,33 \mathrm{~mm}$, konsentrasi $0,8 \%$ yaitu $9 \mathrm{~mm}$, konsentrasi 1,6\% yaitu $12 \mathrm{~mm}$. Bakteri Vibrio chlolerae pada konsentrasi $0,4 \%$ yaitu $9 \mathrm{~mm}$, konsentrasi $0,8 \%$ yaitu 10 $\mathrm{mm}$, konsentrasi $1,6 \%$ yaitu $12 \mathrm{~mm}$.

Dari hasil analisis statistik pada tabel anava menunjukkan bahwa aktivitas antibakteri ekstrak etanol buah belimbing wuluh (Averrhoa bilimbi L.) pada beberapa bakteri uji, hasilnya signifikan (berbeda nyata) karena nilai $F$ hitung $(3,68)$ yang lebih besar dari pada nilai $\mathrm{F}$ tabel $5 \%(2,77)$ dan lebih kecil dari nilai $\mathrm{F}$ tabel $1 \%$. Sedangkan adanya variasi konsentrasi $(0,4 \%, 0,8 \%$ dan $1,6 \%)$ yang diujikan menunjukkan bahwa hasil yang non signifikan (tidak nyata) karena nilai $\mathrm{F}$ hitung $(3,33)$ lebih kecil dari pada $\mathrm{F}$ tabel $5 \%(3,74)$ dan $1 \%(6,51)$.

\section{KESIMPULAN}

Berdasarkan hasil penelitian yang telah dilakukan terhadap sampel buah belimbing wuluh (Averrhoa bilimbi L.), maka dapat disimpulkan :

Ekstrak etanol buah belimbing wuluh (Averrhoa bilimbi L.) pada konsentrasi terendah $0,4 \%$ telah mampu memberikan aktivitas antibakteri terhadap bakteri Shigella dysenteriae, Salmonella typhi, Pseudomonas aeruginosa, Vibrio cholerae, Escherichia coli, dan Staphylococcus aureus.

\section{DAFTAR PUSTAKA}

Chusnie T.P.T., Lamb AJ., 2005, Antimicrobial activity of flavonoids, Journal of Antimicrobial Agent, Vol. 26 : 343-356.

Hembing, W., 2008, Ramuan Lengkap Herbal Taklukkan Penyakit, Niaga Swadaya, Jakarta.

Herlih, 1993, Pengaruh Air Perasan Buah Belimbing Wuluh (Averrhoa bilimbi L.) terhadap Kadar Kolesterol Serum Darah TikusPutih,(http://warintek.riste k.go.id/pangan kesehatan/tan aman obat/pt/buku08. pdf., diakses 30 Maret 2007).

Muhlisah, F., 2007 , Tanaman obat keluarga (TOGA), Penebar, Swadaya, Jakarta. 
Uji Aktivitas Antibakteri Ekstrak Etanol Buah Belimbing Wuluh (verrhoa bilimbi L.) Asal kota watampone

Parikesit, M., 2011, Khasiat dan manfaat belimbing wuluh Penerbit, stomata, Surabaya.

Prayogo, Rahardja S.B., Putri W.R., 2011, Uji Potensi Sari Buah Belimbing wuluh (Averrhoa bilimbi L.) dalam menghambat pertumbuhan

bakteri
Aeromonas salmonicida smithia Secara IN VITRO, Jurnal Imliah Perikanan dan Kelautan Vol.3 No.2.

Wijayakusuma, H., 2006, Ramuan Tradisional Untuk Pengobatan Darah Tinggi, Penebar Swadaya, Jakarta. 